\title{
Evaluating the Agile-Stage-Gate Hybrid Model: Experiences From Three SME Manufacturing Firms
}

\author{
Edwards, Kasper; Cooper, Robert G.; Vedsmand, Tomas; Nardelli, Giulia
}

Published in:

International Journal of Innovation and Technology Management

Link to article, DOI:

10.1142/S0219877019500482

Publication date:

2020

Document Version

Peer reviewed version

Link back to DTU Orbit

Citation (APA):

Edwards, K., Cooper, R. G., Vedsmand, T., \& Nardelli, G. (2020). Evaluating the Agile-Stage-Gate Hybrid Model: Experiences From Three SME Manufacturing Firms. International Journal of Innovation and Technology Management, 16(8), [1950048]. https://doi.org/10.1142/S0219877019500482

\section{General rights}

Copyright and moral rights for the publications made accessible in the public portal are retained by the authors and/or other copyright owners and it is a condition of accessing publications that users recognise and abide by the legal requirements associated with these rights.

- Users may download and print one copy of any publication from the public portal for the purpose of private study or research.

- You may not further distribute the material or use it for any profit-making activity or commercial gain

- You may freely distribute the URL identifying the publication in the public portal 


\title{
EVALUATING THE AGILE-STAGE-GATE HYBRID MODEL: EXPERIENCES FROM THREE SME MANUFACTURING FIRMS
}

\author{
Kasper Edwards, Robert G. Cooper, Tomas Vedsmand and Giulia Nardelli
}

\begin{abstract}
To cite this article: Edwards, K., Cooper, R. G., Vedsmand, T., \& Nardelli, G. (2019). Evaluating the AgileStage-Gate Hybrid Model: Experiences From Three SME Manufacturing Firms. International Journal of Innovation and Technology Management. https://doi.org/10.1142/S0219877019500482
\end{abstract}

To link to this article: https://doi.org/10.1142/S0219877019500482

Published online: 2. Aug 2019

\begin{abstract}
Agile-Stage-Gate is a hybrid product development model that integrates elements of both Agile and Stage-Gate to help companies realize the strengths of both. Recent studies show positive results in manufacturing companies, although SMEs are notably absent despite being the majority. This article reports results of a test of the model in three deliberately-chosen manufacturing SMEs. Results were improved: time to market, overall new product process, higher success rate. Agile required adaptations and novel solutions were found by the test firms. The positive results suggest that Agile-Stage-Gate must be considered a recommended product development approach in SME manufacturers.
\end{abstract}

Keywords: Agile-Stage-Gate hybrid model; Evaluation; Manufacturing; small and mid-sized enterprises.

\section{Introduction}

Manufacturers have traditionally relied on a gated process, such as Stage-Gate*, to drive their new product projects from idea through to commercialization. When Agile Development was introduced by IT-software developers in the mid-late 1990s, strong positive performance results were reported [Begel and Nagappan (2007)]. Thus, a handful of leading manufacturing firms began to experiment with this new development methodology [Millward et al., (2006); Walters et al., (2006), Begel and Nagappan (2007), Tura, Hannola, \& Pynnönen, (2017a)], starting about 2013. Initial results were exceptionally encouraging [Sommer et al. (2015)], and consequently more manufacturers adopted the new method, typically within their existing gating processes. Recent studies continue to show positive results for manufacturers [Invention Centre (2018); Schmidt et al. (2018)].

\footnotetext{
* Stage-Gate ${ }^{\circledR}$ is a legally registered trademark of R.G. Cooper (and Associates Inc.) in the EU and Canada; and of Stage-Gate International in the USA.
} 
One noticeable void, however, is that all the reported cases and studies done on manufacturers and their use of Agile Development since 2013 are for large, often multinational corporations, such as GE, Honeywell, Volvo, and LEGO. Noticeably absent are any mentions of small and mid-sized enterprises (SMEs) in the manufacturing sector, and their experiences and results with this new Agile Development approach. This void is particularly evident when one realizes that SMEs represent the great majority of firms in a modern economy; that they provide most of the new job creation; and further, that SMEs are responsible for much of product innovation!

This article reports the results of a test of this new methodology, notably the Agile-Stage-Gate model (ASG), in three SME manufacturing firms. This test or experiment was sponsored by the Danish employers' organization, The Confederation of Danish Industry (DI), and funded by the Danish Industry Foundation, as a way to probe whether or not this new approach was suitable for SME manufacturers in that country. The new model was careful introduced to the three firms with considerable training and coaching, and then their experiences, challenges and performance results were observed for a test development project done over a six-month period. In particular, the unique approaches and "fixes" that these firms evolved when dealing with the issues and challenges of this new way of working provide a useful guide to other SME manufacturers that may wish to adopt this faster and more responsive approach to new-product development (NPD).

\section{Background}

\subsection{Agile Development in the software world}

Agile software development is an umbrella term for a set of frameworks and practices based on the values and principles expressed in the Manifesto for Agile Software Development and its 12 Principles [Agile Alliance, 2019); Beck et al. (2001)]. Ultimately, Agile is a mindset based on the values contained in the Agile Manifesto, values and principles that provide guidance on how to create and respond to change during software development and how to deal with uncertainty. Agile software development methodologies rely on iterative and incremental processes in which product requirements and technical solutions evolve through collaboration between self-organizing, cross-functional teams [Agile Alliance, (2019), Gonzalez, (2014); Tura et al., (2017); Birgün and Cerkezoglu, (2018)].

When Agile emerged in the mid-late 1990s, its methods were seen as the solution to many problems in software development that traditional "waterfall" development processes could not deal with. These traditional processes focus on a big, long-term goal: a final product and its major features. But requirements change rapidly in software projects: The product features defined when the project was initially planned were often no longer valid by the end of a 12- to 18-month development cycle [Tura et al., (2017a)]. And, as Reagan [2012] puts it, "it's hard to alter course when you're being swept down a large 
waterfall ... Too much up-front planning means too much change management downstream".

Agile was introduced to deal with these issues through adaptive planning, evolutionary delivery, a time-boxed iterative approach, and flexible response to change. Beck and colleagues [2001] coined the term Agile in their Agile Manifesto, which elaborated a set of 12 supporting principles, including 1) working software to be delivered quickly and iterated frequently (in cycles of weeks rather than months), and 2) working software to be the principal measure of progress.

\subsection{Agile Development basis}

Agile, specifically the Scrum version, is a set of software development methodologies that breaks the development process into a series of short, iterative, incremental sprints, each sprint being typically one to four weeks long [Beck at al. (2001); Schwaber (2004); ScrumInc (2017)]. The main components of the process are [ Hannola et al., (2012), Cooper and Sommer (2018)]:

- Sprint planning meeting: At the beginning of each sprint, the development team meets to agree on what it can accomplish in the sprint and creates a task plan.

- Daily stand-up meetings: During the sprint, the team meets every morning to ensure that work is on course to accomplish the sprint goals, review what has been accomplished in the last 24 hours and what should be done in the next 24, and resolve problems; these meetings are also sometimes called scrums.

- Demo: Towards the end of each sprint, product increments or new features developed in the sprint are demonstrated and validated with stakeholders, including both management and customers.

- Retrospective meeting: At the end of each sprint, the team meets to review how team members worked together and how the team can improve.

The development team then plans and begins the next sprint based on customer and management feedback on what needs improving and what needs to be developed next. Product requirements and technical solutions, and even the project plan, thus evolve over the development cycle. There is no traditional project leader or project manager in Agile. Rather, the process relies on a new set of defined roles:

- $\quad$ The scrum master, a servant-leader for the team, ensures that the team adheres to Agile theory, practices, and rules.

- The product owner, a member of management, often a senior marketing person, represents the product's stakeholders and the voice of the customer, and guides the team (for example, meets with the team at sprint planning meetings).

- The development team, a dedicated project team that does the development work; the development team is usually physically co-located.

The development team's work is visible to all, tracked, and monitored via a set of visual scheduling and tracking tools that are displayed in the team room: 
- The product backlog displays a list of features to be built, and the sprint backlog lists those features to be completed in the current sprint.

- The Kanban board (also sometimes called the scrum board) organizes sprint tasks in three categories: to do, doing (underway), and done.

- The burndown chart is a two-dimensional graph that shows progress versus the plan; the sprint time period is on the $\mathrm{x}$-axis and the sprint task times are on the y-axis.

\subsection{The classic gating system used by manufacturers}

Traditionally, many manufacturers of physical products have relied on a gating or StageGate $^{\circledR}$ system to drive ideas through development and into market [Cooper and Sommer (2016b)]. Such gating models have been widely adopted by manufacturers in both B2B and B2C sectors [Griffin (1997); Ettlie and Elsenbach (2007); Grönlund, Sjödin and Frishammar (2010); Cooper (2017); Tesch, Brillinger and Bilgeri, (2017)]. As Sommer et al. [2013] explain: "The sequential model is the most broadly used model within PD [product development] project management [Griffin (1997); Grönlund et al. (2010); Ovesen (2012)]. It is often referred to as a stage-gate model, inspired by the Stage-Gate ${ }^{\circledR}$ model introduced by Cooper in 1983 [Cooper, 1983; Griffin (1997)]. Here, project tasks are divided into a number of sequentially dependent stages with well-defined gates in between" [Nicholas and Steyn (2012)].

In practice, a stage-gating system breaks the idea-to-launch process into a series of five or six discrete stages or phases, beginning with "Discovery" or "Idea Generation" and moving through to "Product Launch" and beyond (see Figure 1). Each stage costs more than the preceding stage, so that the process is very much an incremental commitment one, much like buying a series of options on a property - thus risk is mitigated. Each stage contains a set of known success-drivers and tasks, such as voice-of-customer studies, factbased product definition, and robust front-end homework, so that best practices are built into every development project by design.

Preceding each stage is a gate, where Go/Kill and investment decisions are made: Are we doing the right project, and are we doing this project right? At gates, poor projects are culled out, so that resources are funneled to the best projects as their potential becomes clearer. Stage-Gate is also cross-functional (that is, involves people from marketing, sales, and operations alongside technical personnel). Gating models in general are considered to be planned-based approaches.

While gating methods have proved very effective in most development applications, there have been criticisms as well [Becker (2006); Lenfle and Loch (2010); Cooper (2014)]. Such models are seen as being too linear, too rigid, and too planned to deal with today's fast-paced and often quickly-changing world and to handle more innovative or dynamic projects: Simply stated, Stage-Gate is not adaptive enough and does not encourage experimentation - product definitions and project plans tend to be locked in too early [Sætre \& Brun, (2013)]. Jetter et al. [2016] expand on this concern about introducing too much rigidity into organizational routines and cultures: "To obtain approval, product development teams may commit to precise project parameters and freeze product specifications early in the development process, even against their better 
judgment". Committing early to features and a schedule means that compromises will be needed late in the project; early commitments to major design features, long schedules, long feedback loops, and the re-planning inherent in traditional product development processes create inefficiencies and slow the development cycle. Sethi and Iqbal [2008] similarly note that with a strictly enforced objective, and frequently applied gate review criteria, the project is likely to lose its flexibility and the ability to change direction (too early commitment to design and specs). And there is also loss of learning and a failure to integrate new information gained during the project and make changes in plans when the project is approved after initial gates. "This adverse effect of project inflexibility on learning is worsened when there is turbulence in the technological sector of the environment [Sethi and Iqbal (2008)].

Stage-Gate is also accused of contributing to a rigid and fixed mindset. Jetter et al. [2016] note that "after approval, a project team may engage in a project execution mindset and focus on the project plan and whatever is required to sail through the next gate, rather than making changes to the project in response to new market and technology insights" [Sethi and Iqbal (2008)]. The fact that a project has passed formal reviews involving $\mathrm{g}$ high-level management makes it difficult later to propose an alternative course of action [Svejvig \& Andersen, (2015), Daly et al. (2012), Budak and Ustundag, (2016)].

Another criticism is that Stage-Gate is not context-based—one size should not fit all. For example, Salerno et al. [2015] find that in practice "there is no single innovation process that fits all types of innovation projects"; and that there are different processes that better deal with contingencies of a project, and "different ways of treating uncertainties in innovation processes". Almost two decades ago, Ajamian and Koen [2002] proposed a special version of stage-gate to handle technology development (new science) projects.

Yet another critique is that the gates in the process are thought to be too structured or too financially based, and the system is too controlling and bureaucratic, loaded with paperwork, checklists, and too much non-value- added work [Becker (2006); Lenfle and Loch (2010)]. Sethi and Iqbal [2008] also note that Stage-Gate is too time-consuming, has time-wasting activities and bureaucratic procedures, and restricts learning opportunities.

Some experts have taken issue with these criticisms, arguing that most are due to faulty implementation [Becker, (2006)], while some deficiencies have been corrected in more recent evolutions of Stage-Gate [Cooper, (2010)]. For example, now there are multiple versions of Stage-Gate to handle proejcts of different size, complexity and risk; and iterative experimentation loops have been built into Stage-Gate to enable team to learn and alter the project's direction or product's design [Cooper, (2008)]. But issues do remain, and thus a handful of leading firms are rethinking and re-inventing their idea-to-launch gating system.

Traditional project management methods have been typically employed within the stages of new-product gating models, and have been similarly criticized. Svejvig and Andersen [2015] note that classical project management needs to be rethought in light of new realities. Atkinson et al. [2006], who identified a range of sources of uncertainty, assert that: "More sophisticated efforts to recognize and manage important sources of uncertainty are needed." Similarly, Thomas and Mengel [2008] argue that complexity, uncertainty and 
chaos play an increasingly important role in projects and project environments. To deal with complexity, alternative perspectives such as evolutionary management and selforganization, much as what is found in Agile development, are proposed [Saynisch, (2010), Sætre \& Brun, (2013); Svejvig \& Andersen, (2015); Lee, St.John, Fong and Bao, (2018)]. Finally, Kreiner [1995] points out that people involved in projects must recognize that the originally intended outcomes will not necessarily remain relevant over time since the environment often drifts. The project manager must thus remain flexible, and be prepared to adapt the plan; otherwise the project managers risks "taking the plans literally" [Kreiner (2012)].

\section{Moving to the Agile for Manufacturers}

\subsection{The Agile-Stage-Gate hybrid model}

As Agile took root in the software industry, some larger software firms with existing gating systems built Agile into their development processes, thereby creating hybrid models. Their experience revealed that Agile and Stage-Gate can be used together to advantage: Karlstrom and Runeson $[2005 ; 2006]$ note that, "Agile methods give the Stage-Gate model powerful tools for microplanning, day-to-day work control, and progress reporting". Gating models are generally "plan-driven models," whereas Agile is more "plan and build on the fly." Boehm and Turner [2004] argue the two are complementary: Stage-Gate is a comprehensive idea-to-launch system and a macroplanning process while Agile is a microplanning project management methodology.

Agile-Stage-Gate has recently begun to interest developers of physical products, some as early as 2013 [Cooper, (2016); Kortelainen and Lättilä, (2013)]. Conforto et al. [2014] revealed that some Brazilian manufacturers are experiencing the use of some Agile management practices even though they do not belong to the software industry sector. Project management practitioners are successfully adapting Agile practices because they were struggling with their current and formalized project management processes when undertaking innovative projects [Bers \& Dismukes, (2012); Jahanshahi \& Brem, (2017); Svejvig \& Andersen, (2015)]. Approaches that combine macro- with micro-management tools, methods and processes for new product development are, for example, design thinking [Ben Mahmoud-Jouini, Midler, \& Silberzahn, (2016)], lean-startup [Gudem, Steinert, \& Welo, (2014); Yordanova, (2018)] and real options reasoning [Jahanshahi \& Brem, (2017)]. Sommer et al. [2015] report the successful use of Agile in five Danish manufacturing firms, who simply utilize Agile methods within their existing stage-andgate system; performance results were positive. In hardware firms, Agile was often first adopted by IT groups, whose initial results encouraged R\&D groups working on hardware development to experiment with Agile [Cooper and Sommer (2016b)].

A hybrid model that integrates elements of both Agile and Stage-Gate can help manufacturing companies capitalize on the strengths of both. The agility construct in the context of product development in a manufacturing firm is defined as "the capacity to change the project plan and the active involvement of customer in the development process" [Conforto, 2016)], thereby enabling verifying or adjusting the product's design as 


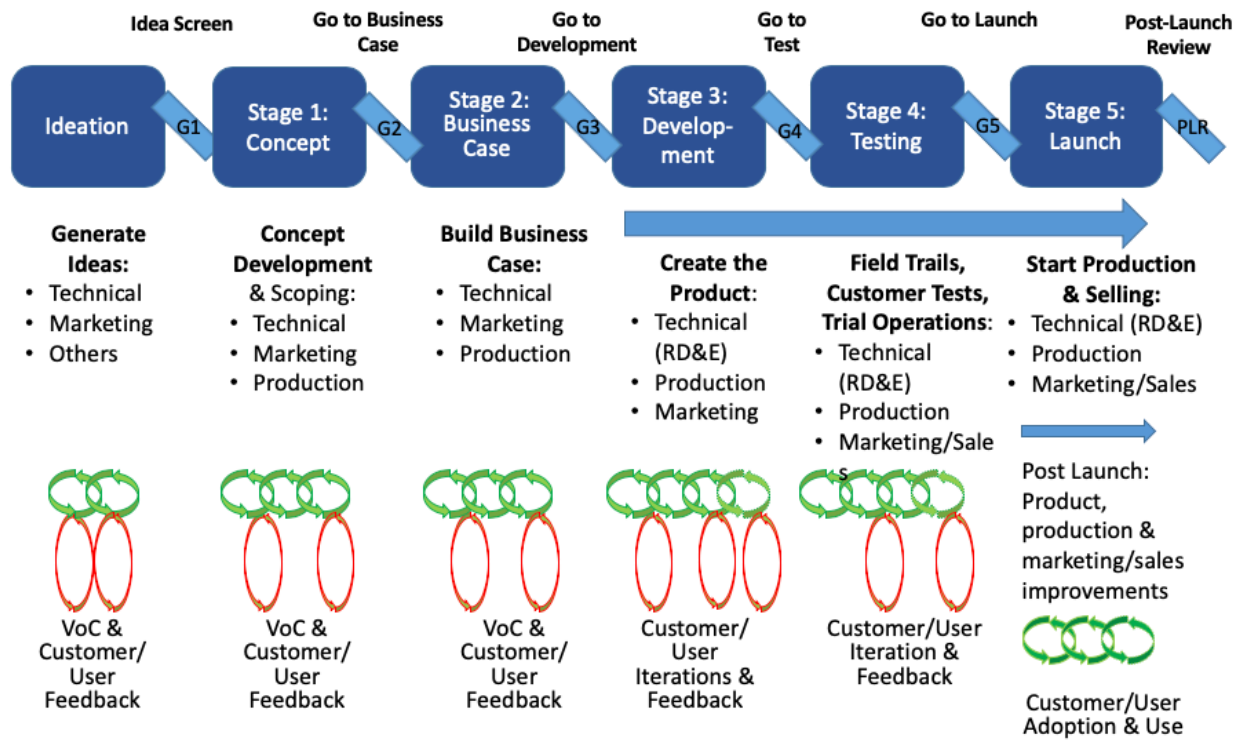

Fig. 1. The integrated Agile-Stage-Gate hybrid model - a typical 5-stage, 5-gate Stage-Gate idea-to-launch system, with Agile sprints (green) and feedback loops to customers (red) built into each of the stages.

the development proceeds. Such a hybrid Agile and gating model for manufacturers has been described in some detail [Cooper (2014; 2016); Cooper et al. (2019); Cooper and Sommer (2016a; 2016b; 2018); Sommer et al. (2015)]. The term "Agile-Stage-Gate" hybrid model was coined by Sommer et al. [2015].

\subsection{How Agile-Stage-Gate works}

In practice, an Agile-Stage-Gate hybrid model for manufacturers embeds the Agile way of working within the stages of Stage-Gate as in Figure 1, replacing traditional project management tools and approaches, such as Gantt charts, milestones, and critical path planning, with Agile project management tools and processes. The project's stages Development, for example - are broken into short time-boxed increments called sprints or iterations, each about 3-4 weeks long (the small green circles in Figure 1), but often longer [Cooper et al. (2019)]. For example, Honeywell uses eight-week iterations for hardware development (versus two-week sprints for software), while Corning employs 60-90-day planning cycles or iterations [Cooper and Sommer (2018); Cooper (2014)]. This longer time allows the team to realistically produce something that they can demo. 
As in Agile-Scrum for software development, in Agile-Stage-Gate for manufacturers, each sprint is preceded by a sprint planning meeting: The project team agrees on a sprint goal (what they can accomplish in that sprint), and identifies the tasks needed - see the sprint circle in Figure 2. Teams meet regularly in stand-up or scrum meetings to discuss progress, synchronize their project and tasks, and resolve issues, but

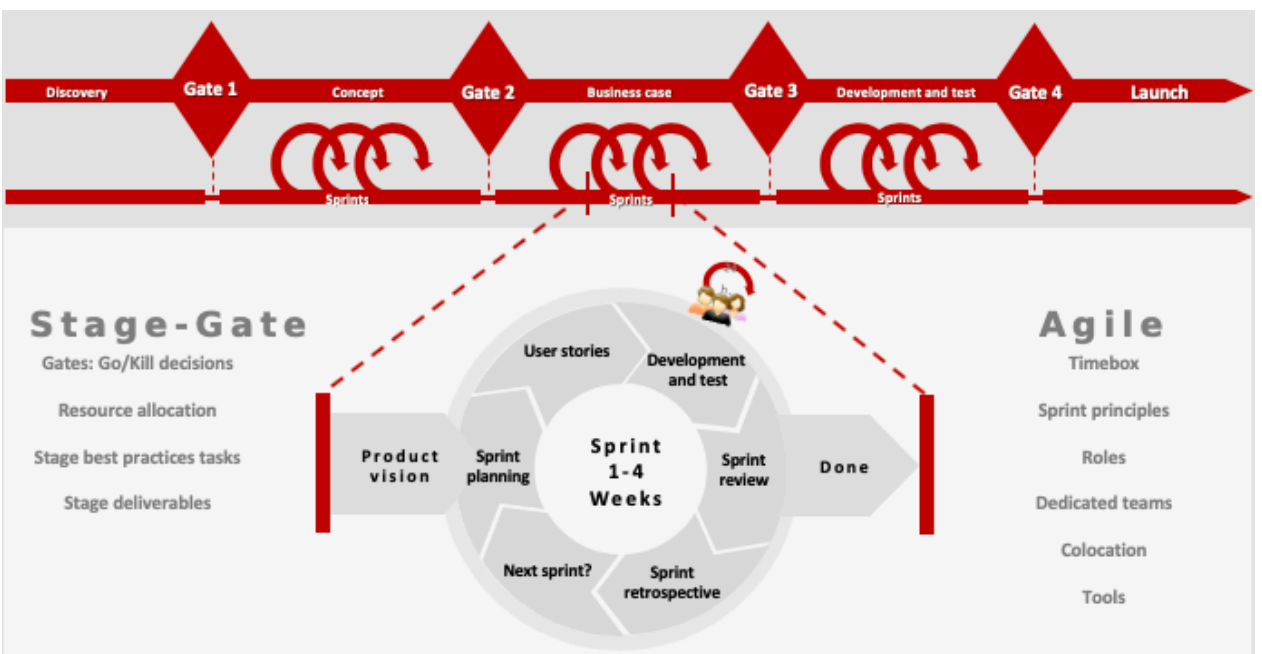

Fig. 2. The SME adapted Agile Stage-Gate used in the test projects [Adopted from Vedsmand et al. (2017a)]

less frequently than in the software-Agile system, typically 2-3 times per week rather than daily [Cooper (2016); Cooper et al. (2019)].

At the end of each sprint, the project team produces "something tangible" that can be demonstrated to stakeholders, including management. In the case of some, but not all, iterations, the demo is to customers or users, again to seek feedback and validation, and to identify corrections needed, notably to the product's design, features and functionality. For example, a study of 138 manufacturers using Agile plus gating found that the median interval between prototypes demo'd to customers was 17-24 weeks; that is, much less frequently than at the end of each sprint iteration [Invention Centre (2018)]. Each sprint is followed by a retrospective meeting at which progress is reviewed and lessons for the next sprint are identified, including feedback from the customer.

\subsection{Where Agile-Stage-Gate is employed}

Initially, Agile was employed mainly in the technical stages, namely Development and Testing, in a firm's Stage-Gate system, Stages 4 and 5 in Figure 1. With maturity, manufacturing firms used Agile-Stage-Gate for more than just these two technical stages, namely in the pre-development stages, for example to develop the concept and to assess feasibility [Vedsmand et al. (2016)]. Further, these manufacturing firms do not use the new method for all projects: Indeed, the Invention Centre [2018] in Germany reports that the great majority of manufacturing firms using Agile Development (62\%) do less than 25\% of their projects with Agile. Agile is usually reserved for larger projects that are more ambiguous (higher uncertainty) and risky. 


\subsection{Positive performance results for manufacturers}

The results from the early adopters of Agile-Stage-Gate have been quite positive [Cooper (2016); Cooper and Sommer (2016a; 2016b). The study of Danish manufacturing firms that implemented Agile-Stage-Gate identified major benefits [Sommer et al. (2015)]. The hybrid model, the study found:

- increased design flexibility;

- improved productivity, communication, and coordination among project team members;

- drove better focus on projects, resulting in better prioritization of time and effort; and

- raised team morale.

Since then, a number of manufacturers have adopted Agile, or facets of it, and results continue to be very positive [Gonzalez, (2014), Sætre \& Brun, (2012), Tura, Hannola, \& Pynnönen, (2017b)]. A large-sample study of 228 German manufacturing firms using Agile [Schmidt et al. (2018)] revealed that the new model increased development productivity, yielded higher success rates, and resulted in shorter development times. However, for all six key performance metrics used, the expectations on these metrics were higher than the results achieved: That is, the hype exceeded results for this new Agile method. Nor were the performance metrics used "hard metrics: They were all qualitative (the opinions of participants in the user firms). A second large-sample study of 130 European manufacturing firms revealed positive results as well [Invention Centre (2018)]: higher team morale, improved ability to handle uncertainties and changing situations, and better customer orientation. All the studies and results cited above, however, were for large manufacturing firms.... which begs the question, does Agile-Stage-Gate work as well for smaller manufacturers? And what modifications must smaller firms make to the new model work?

\subsection{Agile-Stage-Gate Challenges and Issues in Practice}

Despite its preliminary positive results, Agile-Stage-Gate also pose challenges. AgileStage-Gate combines macro-project management tools with micro-activities to perform on a daily basis. While the combination can enhance knowledge transfer and strengthening of tacit knowledge [Hannola et al., (2012)], it also introduces new procedures in already burdened innovation systems. Adding new methods and tools to pre-existing innovation management systems can saturate employees' ability to be flexible, and thus be counterproductive. Furthermore, gating methods are not always adopted, especially within the context of SMEs [Salerno, Gomes, Silva, Bagno, \& Freitas, (2015)]. In these cases, Agile-Stage-Gate might prove even harder to adopt and use, as it introduces two different sets of tools, methods and processes for innovation management.

The flexibility that Agile-Stage-Gate offer can only be obtained if relevant technical and managerial skills are available to support the innovation project [Judi \& Beach, (2010)]. In fact, and especially within SMEs, the implementation of an effective new product development process is the main distinguishing factor between the best and worst performing companies [Millward et al., (2006)]. Without support from management, 
employees would have issues adapting to Agile-Stage-Gate, which combines two competing performance management systems [Hannola et al., (2012), Svejvig \& Andersen, (2015)]. Therefore, the methods, tools and processes offered by Agile-Stage-Gate will have most impact if the employees and managers understand and commit to its grounding principles [Walters, Millward and Lewis, (2006)].

Considering that manufacturing firms only recently begun to work with this development method, it is not surprising that there are only few empirical studies on AgileStage-Gate. The available studies, however, confirm that in practice implementing AgileStage-Gate in the manufacturing sector has not been easy, and many challenges and apparent conflicts and inconsistencies have been identified. The early Danish study revealed some immediate negatives, namely delays due to the difficulty of finding dedicated team members, difficulties in linking project teams to the rest of the organization, mismatches between the requirements of Agile and the company's reward system, and a sense that the system was still too bureaucratic [Sommer et al., 2015)]. The Brazilian study also identified potential barriers, issues and challenges faced in Agile implementation in more "traditional industries" [Conforto et al., (2014)]. These issues include the need to assign full-time dedicated project teams; the challenge of co-locating all project team members; the difficulty in creating large multidisciplinary teams (with all project competences involved); the challenge of involving customers with a high degree of influence in project development; and the superficial involvement of suppliers [Bhatia, Cheng, Salek, Chokshi, \& Jetter, (2017)]. Still other challenges for manufacturers adopting Agile practices have been identified, including a lack of scalability (to larger, more complex programs with multiple sub-project; or to global projects), a proliferation of meetings, and a lack of management buy-in due to the differences from familiar gating systems [Cooper and Sommer, (2016b)].

The more recent and large-sample German study also voiced some words of warning [Schmidt et al. (2018)] and major difficulties were encountered, however, in:

- embedding Agile teams into the classic organizational structure,

- interpreting Agile practices for physical products, and

- modularizing the product or project (breaking the project into increments that could be undertaken within a single sprint).

\section{The Test Methodology}

\subsection{Declaration of roles}

In this project, the authors have assumed different roles in implementation and data collection. All authors have contributed to developing the tailored Agile-Stage-Gate model that was tested. The first and fourth author interviewed developers and administered the surveys. The third author was funded as part of the project to teach and coach the participating development teams. Two observers from DI participated during teaching and coaching session with the purpose of learning the method. The first, third and fourth author and two observers from DI participated in the final evaluation workshops with managers. 


\subsection{The three SME firms}

To test and evaluate the Agile-Stage-Gate system for smaller manufacturing firms, a longitudinal in-depth multi-case approach was elected. Three Danish SMEs that were about to begin an innovation project and also who were willing to test Agile-Stage-Gate were identified by DI and selected as test companies; the study was funded by the Danish Industry Foundation. DI selected the companies from their network based on the following criteria: 1) manufacturing and development was done in-house, 2) the company was about to initiate a product development project, 3) the company did not use Agile in their current development practice, and 4) the company was willing to use Agile-Stage-Gate in their project. Characteristics of the three firms are in Table 1.

Prior to the test, the Agile-Stage-Gate system was tailored for SMEs using a participatory approach: bringing together experienced innovation managers from four large manufacturing firms and an SME which were already experienced in the use of AgileStage-Gate (LEGO, Danfoss, Grundfos, Coloplast, and the SME ForeNAV), together with Agile-Stage-Gate experts (consultants and coaches) [Nardelli and Edwards (2018)]. The tailored Agile-Stage-Gate system was published as a 20-page manual describing AgileStage-Gate and as a supplement manual containing descriptions of relevant tools [Vedsmand et al. (2017a; 2017b)].

Table 1. Characteristics of the three companies participating in the Agile-Stage-Gate test.

\begin{tabular}{llll}
\hline Characteristics & Company A & Company B & Company C \\
\hline Industry & B2B convenience food & B2B audio equipment & B2B radar systems \\
Founded (year) & 2000 & 1992 & 1977 \\
Number of Employees & 142 & 155 & 98 \\
Annual Sales (million Euro) & 35 & 28 & NA \\
Annual profits (million Euro) & 2.0 & 3.3 & 1.5 \\
\hline
\end{tabular}

\subsection{Implementing Agile-Stage-Gate in the Three Firms}

The Agile-Stage-Gate system was tested over a period of six months in 2017.The test project's development teams participated in a joint Agile-Stage-Gate workshop; here the teams were instructed on the Agile-Stage-Gate model, and on the most important methods in both Stage-Gate and Agile. Training was facilitated by the third author and based on the developed manual and tools [Vedsmand et al. (2017a; 2017b)].

Following this training session, the three project teams were then asked to prepare an overall sprint plan: that is, a map showing the approximate number of sprints, an expected timeline for major product releases or deliverables, and a rough estimate of resources (including a map with allocation rates of different competencies and people required for each sprint). Additionally, the teams defined roles: the product owner, scrum master, development team, and stakeholders. And they also outlined for which stages and gates they would use the hybrid model for their project (for example, for Stages 1-3 and 
Gates 1-3 in Figure 1). In order to foster commitment and accountability, each team presented their project and sprint plan at this first workshop.

Project team members in each firm were subsequently trained on location by the third author on more of the details of the Agile-Scrum methods and approach, including:

- the Agile mindset;

- the scrum process and roles;

- events and artefacts, such as daily scrum, demos or reviews, retrospectives, product backlog, sprint backlog, and the definition-of-done; and

- tools such as user stories, the scrum board, and the burndown chart.

Training on Stage-Gate front-end methods, such as design thinking (personas, user-research, and visual prototyping) was also undertaken. All companies received initial coaching on how to apply these new methods and roles, while product owners and scrum masters received intense coaching during the first two sprints with decreasing amount of coaching throughout the rest of the project.

\subsection{Data Collection}

Prior to starting their Agile-Stage-Gate projects, project managers from the test projects were interviewed about their existing product development practices and general information about the company and products by the first author. The project managers were asked to explain the process of the last product they had developed, and to map the sequence of events on a whiteboard. The interviews were recorded, and the drawings of the development processes photographed.

A questionnaire was distributed to all development team members of the three projects $(\mathrm{N}=15)$ before project start (baseline) and after project's end (follow-up). The questionnaire covered Agile development practices such as co-location, sprints with clear goals and deadlines etc. (15 practices and behaviors were gauged via 5-point Likert scaled questions, strongly agree/strongly disagree, shown in Figure 3). The baseline questionnaire was distributed just before the start of the Agile-Stage-Gate project and captures the normal development practice. The follow-up questionnaire specifically asked about the AgileStage-Gate project. This allows an estimate of the effect of the project on Agile practices. Following the six-month test period with their test projects, the test participants were interviewed. Two evaluation sessions were conducted in each company:

(1) an evaluation workshop with management; and

(2) a group interview with project team members.

The evaluation workshops with senior management focused on estimating the effect of Agile-Stage-Gate assessed from a management perspective. Despite efforts to use hard metrics, none of the three companies had metrics in place to precisely track and evaluate development projects. Difficulties in getting hard metrics is not unique to this project or SMEs; for example, in Cooper and Sommers [2018] study, "only one of the six case-study firms had implemented formal metrics". The large-sample German study [Schmidt et al. (2018)] also had to rely on qualitative data. As Brem [2016] notes: “...there are no predefined measures existing — on the contrary: defining success always depends on a subjective view...". Thus, effect measures are managers' estimates, which consisted of 
three elements: First, senior managers shared their experiences and the results of the project. Secondly, the results were discussed with the researcher (first author), DI observers, and the Agile coach (third author). Thirdly, senior managers were asked to evaluate the effect of Agile-Stage-Gate by comparing "your [test] project to similar projects in your company". It was explained that "similar" meant similar in size, scope, complexity. Two managers per firm participated in each of these workshops, and they were asked individually to score their experiences using the following four questions:

(1) Was development time slower, same, or faster (as a percent).

(2) Was development cost higher, same, or lower (as a percent).

(3) Overview of the innovation process (worse, same, better).

(4) Success rate (success probability) for the project (worse, same, better).

Care was taken to avoid unfounded claims as a consequence of social desirability bias of scoring the effect higher. From the first contact with companies, it was highlighted that the project was a test to evaluate if Agile-Stage-Gate was useful to manufacturing SMEs. Managers were asked to explain and exemplify their reasons for their answers to each question in detail. The evaluation workshops were recorded, company presentations collected, and responses recorded. The group interviews with development team members focused on their experiences during the test project using the Effect Modifier Assessment (EMA) method [Edwards and Winkel (2018)]. The EMA-method captures changes in work practices and organization during the Agile-Stage-Gate project period, and assesses whether the changes are a result of the Agile-Stage-Gate method or other contextual factors. By focusing on changes in work practice - simply identifying and explaining how work has changed in the project and not evaluating Agile-Stage-Gate-social desirability bias is minimized. Respondents were asked to elaborate and explain the changes to provide a rich detailed account of the work-practice changes.

\section{Results in the Three Companies}

The three participating companies completed the test on one project each using the AgileStage-Gate hybrid model. The companies had existing development processes resembling Stage-Gate; however the processes were used more like guidelines rather than as a disciplined process. As with most manufacturers, the test companies did not adopt the software version of Agile as is; rather, they were trained in the tailored ASG model, which each firm then slightly adopted to suit their own unique situation - see Table 2.

Table 2. Adoption and use of the tailored Agile-Stage-Gate model in the three companies.

\begin{tabular}{|l|l|l|l|}
\hline $\begin{array}{l}\text { Agile Stage-Gate } \\
\text { Elements }\end{array}$ & Company A & Company B & Company C \\
\hline Project type/scope & Convenience snack & Audio headset & $\begin{array}{l}\text { Modular power } \\
\text { supply }\end{array}$ \\
\hline & & & \\
\hline Team size & 6 & 4 & 5 \\
\hline
\end{tabular}




\begin{tabular}{|c|c|c|c|}
\hline Stage start & Discovery & Discovery & Scoping \\
\hline Stage end & Development & $\begin{array}{l}\text { Development \& } \\
\text { Testing }\end{array}$ & $\begin{array}{l}\text { Concept/Business } \\
\text { Case }\end{array}$ \\
\hline \multirow{5}{*}{$\begin{array}{l}\text { Agile \& innovation } \\
\text { methods }\end{array}$} & Adopted Scrum & Adopted Scrum & Adopted scrum \\
\hline & Design-thinking & User-stories & $\begin{array}{l}\text { Integrated Product } \\
\text { Development }\end{array}$ \\
\hline & $\begin{array}{l}\text { Daily scrum } 2 \text { times } \\
\text { a week }\end{array}$ & $\begin{array}{l}\text { Daily scrum 0-1 } \\
\text { times a week }\end{array}$ & Daily scrum \\
\hline & Personas & Product backlog & $\begin{array}{l}\text { 2-week sprint }+1 \text { - } \\
\text { week development } \\
\text { moratorium }\end{array}$ \\
\hline & Prototyping & Prototyping & \\
\hline \multirow[t]{3}{*}{$\begin{array}{l}\text { Stage-Gate } \\
\text { elements used }\end{array}$} & Early stages & $\begin{array}{l}\text { Full } \quad \text { Stage-Gate } \\
\text { model, } \quad \text { detailed } \\
\text { front-end }\end{array}$ & Early stages \\
\hline & $\begin{array}{l}\text { Scorecards, } \\
\text { criteria }\end{array}$ & & $\begin{array}{l}\text { Scorecards, } \\
\text { criteria }\end{array}$ \\
\hline & Gate meetings & & Gate meetings \\
\hline \multirow[t]{4}{*}{$\begin{array}{l}\text { Adoption after } \\
\text { project end }\end{array}$} & Adapted scrum & $\begin{array}{l}\text { Full Stage-Gate } \\
\text { model (as before } \\
\text { project) }\end{array}$ & $\begin{array}{l}\text { Fencing } \quad R \& D \\
\text { resources }\end{array}$ \\
\hline & $\begin{array}{l}\text { Sprint reviews as } \\
\text { gates }\end{array}$ & $\begin{array}{l}\text { Agile front-end } \\
\text { model adopted }\end{array}$ & $\begin{array}{l}\text { Scrum for } R \& D \\
\text { projects }\end{array}$ \\
\hline & & & $\begin{array}{l}\text { Scorecards with } \\
\text { criteria }\end{array}$ \\
\hline & & & $\begin{array}{l}\text { Stage-Gate under } \\
\text { development }\end{array}$ \\
\hline
\end{tabular}

\subsection{Performance results achieved}

Performance results measured at the senior management workshop are generally positive on four important metrics - see Table 3. Senior management believed that each of the test projects was executed about 20\% faster than previously-done comparable projects, a 
consistent result across all three companies. There were few or no perceived development cost reductions or faster spending-rates of development budgets, however. Company B actually saw an increase in development spending, but only because they added a new activity to the process, namely overseas end-user interviews.

In two of the three firms, senior management believed that the innovation process overall had been improved. Previously, project planning had been ad-hoc and idiosyncratic, and based on the lead developer's own experience. In the test projects, the sprint planning meetings provided a common understanding of what was needed, goals, and next steps for both management and the development team. The third firm already had a tried-and-proven development process that they followed and which was understood by all.

Table 3. Summary of senior managers 'evaluation of the Agile-Stage-Gate compared to comparable innovation projects.

\begin{tabular}{llll}
\hline Performance metric & Company A & Company B & Company C \\
\hline Development time & $-20 \%$ & $-20 \%$ & $-20 \%$ \\
Development cost & Same & $+10 \%$ & Same \\
Overall innovation process & Better & Better & Same \\
Estimated probability of success & Higher & Higher & Higher \\
\hline
\end{tabular}

In all three firms, management concluded that there was a higher probability of success for the test project than for previous comparable projects. This higher success probability was judged to be because, unlike previous projects, the test projects had included user insight via customer interviews, the result being that both management and developers believed the product had a potential customer base and clear market. The enduser interviews also changed the directions of the test projects; for example, in one firm, end-user insights resulted in one product line of accessories being completely canceled because end-users already had a cheap off-the-shelf solution for the envisioned accessory products.

\subsection{Impact on practices and behavior}

The use of Agile-Stage-Gate for the test projects generally had a positive impact on the development teams' behavior and practices. There are improvements in 13 of 15 items, measured before and after the test project, as shown in Figure 3. 
Difference between normal and Agile-Stage-Gate development $(\mathrm{N}=15)$

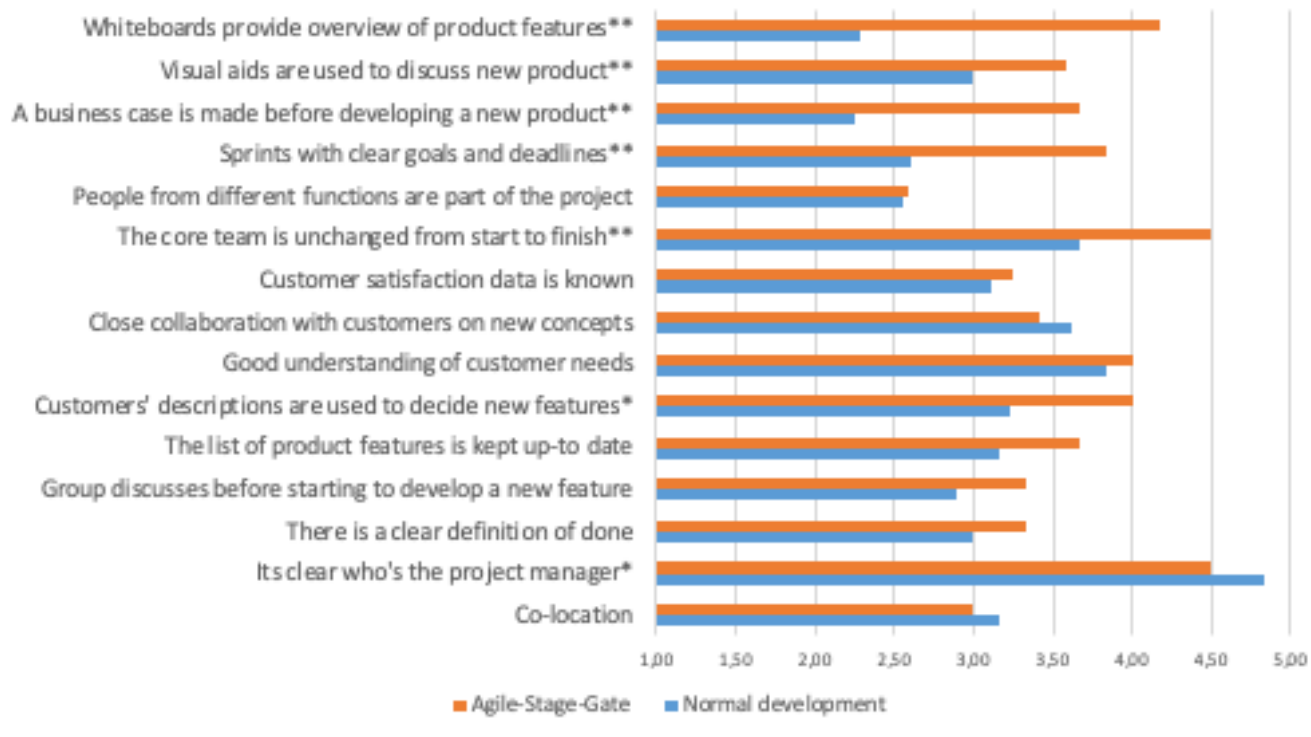

Fig. 3. Effect of Agile-Stage-Gate in the three companies. Measured using a 5-point Likert scale, 1=strongly disagree, $5=$ strongly agree. $*: P<0.1, \cdots: P<0.05$, two-tailed T-test

The behavioral changes in Figure 3 demonstrate that the three companies were generally compliant, and actually put Agile-Stage-Gate into practice in their test projects. And development teams appeared to have adopted some Agile best practices. Of the 13 significant improvements noted in Figure 3, the greatest in descending order of impact are:

- The use of visual displays of product features to be built (e.g., on a whiteboard).

- The development of a strong business case.

- Breaking each stage into defined time periods, each with clear goals and deadlines, namely time-boxed sprints.

- Having a core project team with the same people from the start of project to its end.

- Employing customers' descriptions of product-use situations (for example, through user stories).

- Use of visual descriptions, such as drawings, to facilitate team discussion.

- Having an up-to-date product feature list (for example, the product or sprint backlog).

- Having a team meeting to discuss a new feature before beginning its development on the sprint planning meeting.

But understanding when a product feature or sprint task was completed (the definition of done) improved only marginally. In some areas, the new Agile-Stage-Gate model had surprisingly little or no impact (Figure 3), such as understanding of customer needs and knowledge of customer satisfaction data (complaints, quality issues, etc.). The greatest negative surprise that the survey of development team members showed is that there was a decrease in collaboration with customers on new concepts (even though two of the firms began their projects with customer interviews). The latter may be related to the 
wording of the question that focuses on "new concepts" (no new concepts had been developed at the time the follow-up questionnaire was administered).

In terms of organization, there were also few or no improvements. Development teams minimally had a better understanding of who the project manager was (note: the test projects employed a scrum master to lead the daily scrums, whereas normal projects used a more traditional project manager role). Further, there was no change in the team crossfunctionality or team composition (for example, the inclusion of team members from of other departments in the project). Finally, there was no higher propensity for the team to co-locate, one of the key features of Agile (in fact, there was a slight a slight decrease in co-location).

Finding dedicated resources to work on the projects, a requirement when using Agile-Stage-Gate, also proved problematic. Company $\mathrm{C}$ was the best here, with $60 \%$ of development team members spending more than $50 \%$ of their work-time on the test project - see Table 3. By contrast, two-thirds of the team members in Company A spent $19 \%$ or less of their work-time on the project; while in company B, $75 \%$ of team members spent only $19 \%$ or less of their work-time on the project.

Table 3. Amount of work time spent on the project in the three development teams.

\begin{tabular}{llll}
\hline & \multicolumn{3}{l}{$\%$ of development team } \\
\cline { 2 - 4 } Work-time spent on project & Company A & Company B & Company C \\
\hline $1-9 \%$ & $17 \%$ & $0 \%$ & $0 \%$ \\
$10-19 \%$ & $50 \%$ & $75 \%$ & $0 \%$ \\
$20-29 \%$ & $0 \%$ & $0 \%$ & $40 \%$ \\
$30-49 \%$ & $17 \%$ & $25 \%$ & $0 \%$ \\
$50-74 \%$ & $17 \%$ & $0 \%$ & $20 \%$ \\
$75-100 \%$ & $0 \%$ & $0 \%$ & $40 \%$ \\
\hline
\end{tabular}

A year after the project ended, Companies A and B have both introduced their new products to the marketplace. Initial sales in both companies are promising, and Company B has received critical acclaim for their product [Clark (2018)].

\section{Issues, Learnings and Solutions in Agile-Stage-Gate Implementation}

The three SME firms faced a number of challenges and issues as they employed AgileStage-Gate for their test projects. Modifications, work-arounds, and fixes, some quite clever and novel, were found, however, and provide a guide to other SME firms which are planning to adopt this new Agile-Stage-Gate approach.

\subsection{Sprints or iterations}

To implement Agile-Stage-Gate for their test projects, the three companies generally kept their existing and familiar stages in their current new-product process, but broke the stages into time-boxed sprints. These sprints were often longer than the two-weeks common in 
software-Agile, often 3-4 weeks. And they were of variable length, sometimes lasting as long as eight weeks.

The longer and variable definition of the length of sprints or iterations is at odds with the tenets of software-Agile, where a consistent sprint time helps to create a rhythm or heartbeat, and a short two-week sprint puts some time pressure on team members. However, it is somewhat similar to the practices found in larger manufacturing firms [Cooper, Fuerst and Dreher (2019)], where sprints typically are indeed longer, for example 3-4 weeks or longer, but still consistent in length (that is, non-variable) in order to achieve a rhythm.

\subsection{Daily scrums}

The stand-up or scrum meetings proved to be a key element in achieving positive results in the three test companies. Only one of the three firms held these scrum meetings every day, however, as prescribed in software-Agile. The two other companies held scrum meetings at a lower and also a varying frequency: from twice a week to sometimes even skipping the scrum for an entire week. This lower and variable frequency was somewhat surprising, since the daily scrums were expected to be instrumental in maintaining project momentum; but this practice is partially consistent with practices in larger manufacturing firms, which typically employ 2-3 scrums per week firms [Cooper et al. (2019)].

The scrum meetings served a very important function, ensuring that project members were synchronized with regard to project progress. Synchronization means a common understanding of the project and its current direction: Team members in sync have heard, understood, and accepted the decisions made, allowing the team to keep moving forward without having to revisit past discussions. Synchronization thus requires all team members to be present, and if a meeting is missed, that team member must accept the decisions made and not bring up past discussions and slow the project.

In company $\mathrm{A}$, the project team decided that members not actively participating in development could be excused from the scrum meetings. This proved to be quite negative: These absentee team members had important insights to offer, so when they returned to the daily scrums, past decisions were revisited. The end result was that the team failed to synchronize and continued to discuss and change past decisions, thereby slowing project progress significantly. A further negative effect was that the team never converged on a common understanding of the product, and so kept diverging in idiosyncratic perceptions of the product vision; the design freeze thus came very late.

The strong impact of frequent scrum meetings in the three SMEs highlights the importance of having all team members present at all scrum meetings. Further, the team may be different for each sprint, but during a sprint, team membership must remain constant in order to ensure synchronization.

\subsection{Dedicated teams and resource allocation}

Dedicated teams are a prerequisite for effective Agile development, and the participating companies had all agreed that they would have dedicated teams for their test projects. However, as noted above and in Table 4, none of the three SMEs had team members $100 \%$ 
devoted to the test project, nor even close to $100 \%$. Larger manufacturers in general tend not to have dedicated teams either when using Agile-Stage-Gate, but their team members certainly are more focused (typically $65-70 \%$ of their time) than what was observed in the three SME firms [Cooper and Sommer (2016b; 2018); Cooper et al. (2019)]. Indeed, the test projects saw some team members with less than $10 \%$-time commitment in a sprint, and thus they only participated in the daily scrums. Still, even though they did not commit much time to the project, these team members had special knowledge necessary for the project; thus, their participation in scrums kept the team in sync and allowed these team members so provide their valuable input.

In the test companies, the scrum meetings also inadvertently became a mechanism for resource commitment. Most team members had many other obligations besides the test project, and so they had to navigate and plan their time to try to accommodate the situation. But this multi-tasking posed a significant challenge for resource commitment to the project. In addition to syncing projects, the scrum meetings had an added benefit in that they ensured that team members prioritized the project and kept the project at top of mind. Team members typically manage their own time, which makes their commitments made at scrum meetings very important. Commitments are like a promise, a social contract between the team and the team member; and any team member that does not honor their time commitment will feel shame at the next scrum meeting. As such, the scrum meeting was an effective informal resource allocation mechanism for these SMEs.

\subsection{Dealing with "other tasks"}

In the three SMEs, as noted above, team members had other responsibilities and tasks in their companies besides the test project, thus making the dedicated team requirement of software-Agile a challenge. These "other tasks" typically included providing engineering support for production or undertaking customer support work. SMEs in general have less employee specialization, and thus must spread tasks across the staff available. To accommodate these other tasks, for example Company $\mathrm{C}$ modified the normal sprint rhythm: They used two-week sprints but introduced $a$ one-week project moratorium after each sprint with no work done on the project for that week. This moratorium allowed team members to catch up on their other responsibilities and tasks, and also put a cap or limit on such "other work" and requests. An added benefit was increased respect for the time allocated for development work on the test project, because management had now pushed all non-critical requests into the development moratorium period.

The moratorium at the end of a sprint allows the team to maintain a fixed rhythm, yet still provide resources for other necessary activities. The use of a moratorium may be particularly useful in companies that cannot dedicate $100 \%$ of project team members' times to a project, which is likely true for most SMEs. This concept of an adjusted fixed rhythm, which is understood by everyone in the company, ensures that expectations can be adjusted and met, thereby reducing the potential for conflict.

The development moratorium also allows project team members to work on more than one project at the same time. For example, when a team member completes a sprint on Project X, during its development moratorium, he or she can then do work on a sprint 
in Project Y. The use of a moratorium is particularly relevant in hardware development: Developing physical samples or prototypes or undertaking product testing can be timeconsuming and often have waiting times, and thus there is a need for a team member to be working on several projects at the same time, which this moratorium enables.

\subsection{Co-location of team members}

Co-location is also a facet of software-Agile. Co-location improves speed and productivity, because team member can immediately resolve any development problems face to face. None of the test companies implemented co-location, moving team members to the same room, however. And none reported that there was a frequent need to discuss development issues that warranted team members to be in the same room. One company used collocation for some specific development tasks that required considerable interaction, such as interface design and changes.

This lack of co-location may be a unique facet of using Agile methods for hardware development. Team members have distinct competences: For example, one engineer is an electronics specialist, another is an aluminum casing specialist, and a third a power supply engineer. The competence overlap is small if any, and therefore getting immediate help for a problem is not enabled by co-locating the team.

Co-location served a specific purpose in Company $\mathrm{C}$, where interface issues, such as the redesign of one component, required changes to other components and the structure of the product. This was solved by co-locating the entire team for an afternoon to discuss interfaces. The team used this approach only three times during the project, however.

\subsection{The product backlog and an evolving product design}

One of Agile's tenets is allowing and even encouraging evolving product designs as development proceeds. The sprint or product backlog thus becomes an important visual tool for the team in software-Agile. It is a flexible document that lists the features to be developed during the sprint (or for the project); and the backlog changes as the product's design evolves over the development period. Note that in software, discrete product features can easily be added to or removed by simply writing or deleting lines of code. Typically, these changes do not impact the rest of the software product, and so the software product's design can indeed be readily changed and evolve in response to customer feedback.

An evolving product design and the use of the backlog tool proved to be difficult for physical product development in the three test projects, however. In contrast to software development, in most physical products, features are not discrete, but are intertwined and tied to the overall product design. As an example, in Company $\mathrm{C}$, a change in the power supply PCB would require changes to the exterior casing and also to the placement of connectors through this casing: Small product changes in one area have ripple effects throughout the entire product's design.

In hardware development, the initial design and feature-set thus limit the adding and removing of features later. Design changes are possible of course, but only at the expense of making changes to related components and potentially to the entire product 
design. Because functions and features are difficult to add later, the product backlog becomes relatively inflexible. Instead, in the test projects, the product backlog turned into a project backlog, which showed not just product features to be built, but listed all activities and tasks, both large and small, that needed to be done in a sprint (or in the project).

One solution is a modular product design, whereby the product itself is broken into relatively independent modules; this permits modules to be changed within limits without impacting other modules. A modular design thus accommodates an evolving product design and so allows the product backlog to be effectively used. The product backlog would be organized around modules that had minimal core-functionality and interface specifications. This would allow modules to change functionality in response to customer feedback, and so evolve the product's design. However, none of the SMEs adopted a modular design as a possible solution to their inflexible backlog challenge in their three test projects.

\subsection{User input and creating a customer-based design document}

The most important change in the overall development process was in the front-end of the project, where Company A and B made significant changes and included voice-of-customer work. One of the clear requirements of Stage-Gate is a strong customer orientation and a customer-based product definition [Cooper [2017), chapters 2 and 4]. By contrast, Company B's normal mode of development was driven by classic engineering goals, such as increased miniaturization and improved frequency response. New features in the product were often included because of emotion or assumptions: team members' personal desires; the interest level of the engineers (for example, an "interesting technical challenge"); or assumptions about customer needs and market trends. Engineering interest may be particularly detrimental to market fit, as the assumption is that technology interest aligns with user needs; often there is no obvious user need, however, making the product difficult to sell. Note that a lack of market inputs and direct customer knowledge is the number one reason for new product failure [Cooper (2017)].

Company A transformed their customer experience into personas [Miaskiewicz and Kozar (2011)], whose needs became the target for product development. These personas are in effect characterizations of target customers, particularly in terms of values sought, needs, and wants. In Company B, the voice-of-customer experience, captured in a design document specifying user needs, vision, and business case, became an important facet of the project. This fact-based design document in the test project eliminated the speculation and assumptions typically found in Company B's normal projects: Each time there was a design choice to be made, the design document would be referred to and formed the basis of their discussion and decision. Company C's project was a "build to order" product under contract, and once the bid or order was won, the development team did not have any further direct customer contact. The head of development assumed the role of the customer at demo and review meetings. 


\subsection{The definition of "done"}

All three project teams were focused on the definition of done or DoD, namely the deliverable to be presented at the end of a sprint and at the next demo meeting. Because the demo presents the results of each completed sprint, what must be completed, namely the DoD, thus served as a clear and visible short-term objective for the team during a sprint.

Results for demos were not always a product version or prototype, as in softwareAgile, however. Indeed, the results of work done appeared in many forms, including results of a market analysis; a competitor assessment; visual description of personas on a large cardboard display; a user study; as well as more physical items such as early models of the product: a product concept built from LEGO, or a simple wire prototype.

The requirement to make a demo presentation is an important driver for reaching a milestone and puts great pressure on the team to deliver on time. Project team members in the three firms reported, however, that this was an exhaustive way of working, as there was a tendency to promise too much for each sprint. This over-promising parallels experiences in the software world; over time, teams learn to be more realistic about lower promises, consistent with their ability to deliver.

\subsection{Incorporating Stage-Gate into the development method}

The Stage-Gate facet of Agile-Stage-Gate was not strongly evident in the three test companies, although some elements of Stage-Gate were employed for the test projects, as noted in Table 2. All companies had elements of a gating process in place prior to the project; but it was unclear to what extent they were followed. In the three firms, gate meetings were held to evaluate test project progress, and involved the managing director and the development team. However, the gate meetings focused only on the Agile-StageGate project and did not include other major projects competing for the same resources (looking at other projects normally strengthens the competition between project teams and deals with resourcing issues). The three companies only had one development team each, thus no other large and competing projects underway

Gate meetings differed from those prescribed in a Stage-Gate process. In the test projects, for example, gates were not investment decision meetings and did not yield a Go/Kill decision as is the norm in a standard Stage-Gate system [Cooper (2018), chapters 8 and 9]. Rather, the decision was usually Go, or a change of direction for the project, or mothballing the project (putting it on hold) because something more important arose.

The demo meetings presented the sprint's results at the end of each sprint were somewhat like "mini-gates". All companies completed at least four sprints and held proper demos with the product owner and managing director. The demo meetings often presented more than one solution: For instance, in Company A, eight personas were presented at a demo and four selected for further development. The demo meetings thus become in effect strategy meetings, where the result of the demo was reviewed against the strategy using scorecards; solutions not in line with strategy were discarded. 


\section{Discussion, implications and limitations}

The study revealed that Agile combined with Stage-Gate could indeed be used by SME manufacturing firms for their new-product development projects, and generally gave positive results, for example faster to market. The various stages of Stage-Gate can indeed be subdivided into time-boxed sprints, and run much like sprints as done in Agile in the software domain, although with somewhat longer sprints than used in software development, namely 3-4 weeks. The regular stand-up meetings or scrums were found to be vital to making the system work. Here, all the team members met for a quick update to share knowledge, sync their tasks, and discuss problems. Typically these scrums were held about 2-3 times per week, but not daily as in software-Agile. Where it goes wrong is when all team members are not at the stand-up meetings; thus all-team attendance is mandatory.

The study revealed that the greatest challenge was finding the dedicated team members that the Agile method demands. The lack of people resources has been identified as a problem for larger manufacturing firms as well [Schmidt et al. (2018); Sommer et al. (2015); Cooper and Sommer (2016b)]; but for SMEs, where team members often have multiple roles in their companies, the problem is far worse [Millward et al., (2006); Walters et al., (2006)]. However, it is not realistic to expect companies in general and SME's in particular to make a firm commitment of dedicated resources and free people from other tasks. Yet, strict adherence to the stand-up meetings - at least two times a week - allows companies to enjoy some major benefits of ASG, such as shorter development times and improved quality, the result of having the team assembled when decisions are made.

SME firms may also employ the somewhat unusual solution of a moratorium at the end of each sprint to allow team members to handles their "regular job" tasks for perhaps one week per month. Although not recommended in any of the software-Agile literature and guides, the use of a moratorium seemed to work for the one SME in this study, and might be considered by others. Finally, although more focused teams are essential, the study also revealed that co-location as mandated in software-Agile was not, and indeed in some cases simply impractical.

A significant challenge was the use of the product backlog and an evolving product definition. The product backlog in hardware is less flexible, and the function the backlog serves in software, supporting the evolution of the product consistent with customer desires, is not always possible in hardware developments. Further work is needed to develop the use of the product (or perhaps project) backlog for hardware development.

All three test firms had a Stage-Gate system in place at the outset, but in some cases it was not working well or there was a lack of discipline. One recommendation is that a functioning Stage-Gate system should be in place before implementing Agile within a manufacturing firm. Note that Agile is not a fix for a poor new product process; Agile creates more transparency and thus simply reveals the flaws in the existing system.

\subsection{Implications for management}

Management appear to be the most important stakeholder when implementing and using Agile-Stage-Gate. Therefore, commitment to Agile-Stage-Gate by the management is crucial. For each project where Agile-Stage-Gate methods are to be applied, managers must 
find the dedicated team. Moreover, managers must make sure that team members have time to fulfill the tasks associated to that specific project at an agile pace, including participating regularly into scrum meetings. In fact, teams working with Agile-Stage-Gate methods should be unchanged throughout each project duration, and all members should always be present at scrum meetings. These aspects are important as they ensure consistency in the work carried out by the team, while allowing to avoid re-negotiations between members. Furthermore, consistency in the timing of sprints is important to achieve a working rhythm, which would be disrupted by obligations related to other projects. Consequently, some nonrelated tasks will need to be solved by someone else within the organization. Management must either delegate or accept delay for these tasks while the project is running.

In addition, team integrity during sprints is imperative. Therefore, managers cannot change team composition on a whim but must allow the team to complete their sprints. Naturally, major issues in the company can force managers to pull resources or change direction of a team. However, these impromptu decisions must be an exception and not the norm. In SMEs, specifically, respecting team integrity may be a larger issue, as the short distance between manager and project/team member provide ample opportunity to influence project direction. As resources in Agile-Stage-Gate projects need not be fully dedicated managers can maintain team integrity through proper planning. Used in combination with development moratoria, management should be able to maintain team integrity while also using the resources for other tasks.

Lack of dedicated teams and the fact that team members in SME's will have other responsibilities and tasks imply that management must setup a system for dealing with these "other tasks". These "other tasks" are not related to the project, and yet that cannot be solved/implemented by employees outside of the Agile-Stage-Gate teams. Management must find, and negotiate a suitable system for dealing with these "other tasks". Such methods must satisfy the needs of the other departments. In this project, for example, Company $\mathrm{C}$ used a one-week moratorium following each two-week sprint. Management must further maintain and defend the negotiated method against immediate requests to ensure rhythm for the team. The lack of a dedicated team may manifest itself as team members not participating in the daily scrum to the detriment of team performance. Management must vigorously ensure the full team are always present at the daily scrum meetings.

Moreover, the adaptability of Agile-Stage-Gate should not be seen by managers as an open invitation to make arbitrary change. Agile-Stage-Gate can, and should, be adapted to the practice of the development team while maintaining its fundamental principles. For example, tools such as the inclusion of user input and the definition of done need to be scoped and defined by each team and for each project. However, the adaptation should always be based on Agile-Stage-Gate principles.

Co-location was not a necessary condition for Agile-Stage-Gate in the three companies. However, managers may use this form of collaboration in special situations where changes in one area require changes to the interfaces and other areas. The central management consideration is to reserve this approach for situations that require all team members for longer time than a daily scrum meeting. Managers may also choose to use co- 
location for a subset of the team to quickly clarify and resolve interoperability issues between their functional areas.

Table 4: Implications for management.

\begin{tabular}{ll}
\hline Issue & Management focus \\
\hline Strong management commitment & $\begin{array}{l}\text { Understand and support the agile development } \\
\text { process }\end{array}$ \\
Dedicated team & Identify dedicated team \\
Coordinate resources (team members) with other \\
projects and delegate tasks \\
Ensure team members have time for the project \\
Keep team consistent during sprint
\end{tabular}

$\begin{array}{ll}\text { Daily scrum } & \begin{array}{l}\text { Ensure full team are always present during scrum } \\ \text { meetings }\end{array} \\ \text { Dealing with "other tasks" } & \begin{array}{l}\text { Negotiate system for dealing with "other tasks" } \\ \text { Maintain and defend system from immediate } \\ \text { requests }\end{array}\end{array}$

$\begin{array}{ll}\text { Adapting Agile-Stage-Gate } & \text { Maintain key principles of Agile-Stage-Gate } \\ \text { Co-location } & \text { Use in special situation with interface changes } \\ & \begin{array}{l}\text { May be used for a sub-set of the team with } \\ \text { interoperability issues }\end{array}\end{array}$

\subsection{Implications for research}

In existing research, co-location and dedicated teams have been pointed out as key tools to achieve Agile-Stage-Gate. While our three companies did not require co-location, further research should investigate under which circumstances co-location could be beneficial in manufacturing. Newly assembled teams might find an initial short period of co-location beneficial to learn how to work together and interact. As co-locating may be expensive research should focus on estimating costs and benefits. 
Moreover, it was observed that team members in hardware have distinct competences in hardware development. Research should investigate the effects of team composition aspects such as experience and overlap of competences. This could be coupled with studies of how team members exchange tacit and explicit knowledge while working with Agile-Stage-Gate methods, and compare varied team composition to develop guidelines.

In this study, on the one hand, the one-week project moratorium solved a resource problem. However, such a break may induce overhead costs associated with employees going back and forth to different projects. A deeper look into the positive and negative effects of the project moratorium, and its length, on overall project progress is needed to make stronger recommendations.

None of the companies, on the other hand, used the product backlog as intended in Agile, instead transforming it into a project backlog. In doing so, the case companies did not use the visual tool that is crucial in Agile methods. Research should investigate if a similar functionality can be developed to support hardware development. This functionality might be achieved either through changed design principles such as a modular product design or rethinking the use and content of the product backlog to fit the needs of hardware development.

Furthermore, sprints are generally longer in manufacturing. Research should thus investigate optimal sprint length in relation to type and complexity of the hardware development task. This work may result in recommendations of how to divide the development task into modules or manageable chunks to fit optimal sprint length.

Similarly, further research should investigate the adaptability of Agile-Stage-Gate methods. Dedicated studies should clarify which aspects can, and should, be adapted to specific contexts, and how manufacturers can implement these changes so as to maximize the potential benefits of Agile-Stage-Gate methods.

None of the companies had metrics to track and evaluate development projects and this is not unique. Research would benefit from developing own metrics and develop methods to standardize and compare performance data gathered in companies. These new metrics and methods might allow intra company evaluation before and after assessment, and even allow intercompany comparison

Finally, Agile-Stage-Gate prescribes resource allocation as based on a social contract in the team. Indeed, such social pressure can result in key personal withdrawing from projects to avoid the pressure of such social contracts. Further research should investigate possible negative consequences of this mechanism, e.g. bullying and low motivation to participate in teams. Such consequences and indeed the implementation of Agile-Stage-Gate may be influenced by organizational culture. Research should uncover the role of organizational culture on the implementation of Agile-Stage-Gate methods, and investigate the most and least supportive contexts and their implications.

\subsection{Limitations}

This study is not without limitations and such a real-life test is open to criticism of compliance and desirability bias. A tailored ASG model was developed for the three SMEs, 
and it was attempted to train the test companies to use ASG in the same way in order to allow comparison. The test companies adapted ASG to their own contexts, however, and this raises questions about whether the results are indeed caused by ASG. The questionnaire shows that the use of Agile practices did in fact increase within the companies, and group interviews with developers did not mention other interventions. Moreover, as the questionnaires were sent out before and after the project, when developers had no contact with the Agile coach the impact of social desirability was minimized. However, social desirability can never be completely avoided and may have influenced respondents.

The selection of test companies may favor companies already interested in Agileinspired methods, perhaps amplifying the benefits. However, companies not interested in Agile practices are not a relevant target group, thus making these three test companies comparable in motivation to other SMEs looking to adopt Agile practices.

The use of Danish companies is a direct consequence of the focus of the Danish Industrial Foundation. Software-Agile has been widely adopted and does not appear to favor specific cultural and country contexts, and so hardware-Agile should be no different, suggesting that the results apply to SMEs outside of Denmark.

Hard performance metrics were noticeably missing in all three of the test firms. While the researchers tried to impose metrics, these were largely perceptual. Thus, it would have been more beneficial if the firms had developed, agreed to, and used their own internal metrics, specifically hard metrics to gauge performance, such as time-to-market, on-time performance, meetings sales and profit targets, and so on, to permit more reliable, valid and comparable assessment of performance improvements across the firms. Further, installing metrics at the beginning, as Agile-Stage-Gate is being first implemented, is recommended, so that corrective action can be taken if things do not go well during implementation, thus signaling the need for intervention. Finally, data from such metrics would also help to overcome another potential problem, namely management skepticism. Still, the use of hard metrics does not does not guarantee scientific objective and comparable data, as subject and context differ greatly even within the same firms. In this perspective, perceptual measures do offer a telling indication of the effect of ASG.

\section{Conclusion}

Agile methods borrowed from the software world clearly have a role to play in the development of physical products by SMEs. Three SME manufacturers, using a modified version of Agile for physical new-product, namely Agile-Stage-Gate, generally achieved positive performance results: faster to market, higher success rates, and a better overall new-product process. But the results were perhaps not as strong as might have been expected, given the very positive results reported from larger manufacturers and software developers alike. Moreover, while some of the elements of Agile were adopted by these SME firms, others were not. Indeed, adopting many of the requirements and methods of Agile as practiced in software development proved to be a major challenge for these SME firms, such as finding dedicated or at least focused project teams, co-locating teams, evolving the product's design, using the flexible product backlog, and daily scrums. 
Adaptations of Agile were made, and novel solutions to these challenges and were found by the test firms, however, such as building in a moratorium after each sprint, using scrums but less frequently than daily, employing longer and variable-length sprint iterations, and modifying the definition of "done" to include all results of a sprint, not just product versions. Further, some particularly strong and positive aspects of Agile-Stage-Gate that proved highly beneficial to these firms were uncovered; these included the use of regular scrums with the entire project team present to sync projects, enhance team communication, and also to ensure resource commitment among team members; and building a much stronger customer orientation into the project through voice-of-customer work, the use of personas, and developing user stories early in the project. Overall, and in spite of the challenges, the positive results achieved in this study suggest that Agile-Stage-Gate must be considered a recommended product development approach for use in the context of SME manufacturers.

\section{Acknowledgments}

We appreciate the support of the Danish Industry Foundation project number 2016-0114. We thank the Implementation and Performance Management group at DTU for helpful comments on earlier drafts. We thank the anonymous reviewers for important comments and suggestions for improving the paper.

\section{References}

Agile Alliance (2019). Agile 101, available at: https://www.agilealliance.org/agile101/

Ajamian, G. and Koen, P. A. (2002). Technology Stage Gate: A structured process for managing high risk, new technology projects. In The PDMA Toolbox for New Product Development, edited by P. Beliveau, A. Griffin and S. Somermeyer, New York: John Wiley \& Sons:267-295.

Atkinson, R., Crawford, L., Ward, S. (2006). Fundamental uncertainties in projects and the scope of project management. International Journal of Project Management 24: 687698.

Beck, K., Beedle, M., van Bennekum, A., Cockburn, A., Cunningham, W., Fowler, M., et al. (2001). Manifesto for Agile Software Development. http://agilemanifesto.org/

Becker, B. (2006). Rethinking the Stage-Gate process - A reply to the critics. The Management Roundtable, July 12.

Begel, A. and Nagappan, N. (2007). Usage and perceptions of agile software development in an industrial context: An exploratory study. ESEM '07: First International Symposium on Empirical Software Engineering and Measurement, Washington, DC: IEEE:. 255-264.

Ben Mahmoud-Jouini, S., Midler, C., \& Silberzahn, P. (2016). Contributions of Design Thinking to Project Management in an Innovation Context. Project Management Journal, 47(2), 144-156. https://doi.org/10.1002/pmj.21577

Bers, J. A., \& Dismukes, J. P. (2012). Guerrilla innovation — The accelerated radical innovation model meets the real world. International Journal of Innovation and 


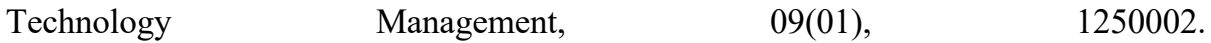
https://doi.org/10.1142/s0219877012500022

Bhatia, A., Cheng, J., Salek, S., Chokshi, V., \& Jetter, A. (2017). Improving the effectiveness of fuzzy front end management: Expanding stage-gate methodologies through agile. PICMET 2017 - Portland International Conference on Management of Engineering and Technology: Technology Management for the Interconnected World, Proceedings, 2017-Janua, 1-8. https://doi.org/10.23919/PICMET.2017.8125390

Birgün, S., \& Çerkezoğlu, B. T. (2018). A Systematic Approach for Improving the Software Management Process. International Journal of Innovation and Technology Management, 16(04), 1940006. https://doi.org/10.1142/s0219877019400066

Boehm, B. and Turner, R. (2004). Balancing Agility and Discipline: A Guide for the Perplexed. Boston, MA: Addison-Wesley: 55-57.

Brem, A. (2016). Learning to become better-backward research as a new approach for analyzing organizations' innovation processes. IEEE Engineering Management Review, 44(4), 26-29. https://doi.org/10.1109/EMR.2016.2623687

Budak, A., \& Ustundag, A. (2016). A RISK SIMULATION AND OPTIMIZATION MODEL FOR SELECTION OF NEW PRODUCT DEVELOPMENT PROJECTS. In Uncertainty Modelling in Knowledge Engineering and Decision Making (pp. 10491055). WORLD SCIENTIFIC. https://doi.org/10.1142/9789813146976_0162

Clark, S. (2018), "DPA d:screet 6061 \& d:fine 6066 headset”, Resolutionmag.com, September 2018, https://www.resolutionmag.com/wp-content/uploads/2018/09/DPAdscreet-6061-dfine-6066-Resolution-V17.6.pdf

Conforto, E. C., Amaral, D. C., da Silva, S.L., Felippo, A. D., and Kamikawachi, D. S. L. (2016). The agility construct on project management theory. International Journal of Project Management 34: 660-674.

Conforto, E. C., Salum, F., da Silva, S. L., de Almeida, L. F. M. (2014). Can Agile project management be adopted by industries other than software development? Project Management Journal, 45, No. 3: 21-34.

Cooper, R. G. (2014). What's next? After Stage-Gate. Research-Technology Management 157, 1, Jan-Feb: 20-31.

Cooper, R.G. (2008). NexGen Stage-Gate ${ }^{\circledR}$-- What leading companies are doing to reinvent their NPD processes," PDMA Visions, XXXII, 3, Sept: 6-10.

Cooper, R.G. (2010). Stage-Gate idea to launch system. in Wiley International Encyclopedia of Marketing: Product Innovation \& Management (Vol.5), B.L. Bayus (ed.), West Sussex, UK: Wiley.

Cooper, R.G. (2013). A process model for industrial new product development. IEEE Trans. on Engineering Management EM-30, 1 Feb. 1983: 2-11.

Cooper, R.G. (2017). Winning at New Products: Creating Value Through Innovation, $5^{\text {th }}$ edition, New York, NY: Basic Books, Perseus Books Group.

Cooper, R.G. and Sommer, A.F. (2016a). The Agile-Stage-Gate hybrid model: A promising new approach and a new research opportunity. Journal of Product Innovation Management, 33, 5, Sept: 513-526. 
Cooper, R.G. and Sommer, A.F. (2016b). Agile-Stage-Gate: New idea-to-launch method for manufactured new products is faster, more responsive. Industrial Marketing Management, 59, Nov: 167-180.

Cooper, R.G. and Sommer, A.F. (2018). Agile-Stage-Gate for manufacturers - Changing the way new products are developed. Research-Technology Management, 61, 2, MarApr: 17-26.

Cooper, R.G., (2016). Agile-Stage-Gate hybrids: The next stage for product development. Research-Technology Management. 159, 1, Jan-Feb: 21-29.

Cooper, R.G., Fuerst, P., and Dreher, A. How Agile development works for manufacturers: Parts 1 \& 2. CIMS Innovation Management Report, forthcoming, 2019.

Daly, J. a., Sætre, A. S., \& Brun, E. (2012). Killing mushrooms: The realpolitik of terminating innovation projects. International Journal of Innovation Management, 16(05), 1-30.

Edwards, K. and Winkel, J. (2018). A method for effect modifier assessment (EMA) in ergonomic intervention research. Applied Ergonomics, 72 (April 2017): 113-120. https://doi.org/10.1016/j.apergo.2018.05.007

Ettlie, J. \& Elsenbach, J. (2007). Modified Stage-Gate regimes in new product development. Journal of Production Innovation Management, 24, 1: 20-33.

Gonzalez, W. (2014). Applying Agile Project Management to Predevelopment Stages of Innovation. International Journal of Innovation and Technology Management, 11(04), 1450020. https://doi.org/10.1142/S0219877014500205

Griffin, A. (1997). Drivers of NPD Success: The 1997 PDMA Report. Chicago, IL: Product Development \& Management Association.

Grönlund, J., Sjödin, D., Frishammar, J. (2010). Open Innovation and the Stage-gate Process: a revised model for new product development. California Management Review, 52, 3:106-131.

Gudem, M., Steinert, M., \& Welo, T. (2014). From Lean Product Development to Lean Innovation: Searching for a More Valid Approach for Promoting Utilitarian and Emotional Value. International Journal of Innovation and Technology Management, 11(02), 1450008. https://doi.org/10.1142/S0219877014500084

Hannola, L., Friman, J., \& Niemimuukko, J. (2012). Application of agile methods in the innovation process. International Journal of Business Innovation and Research, 7(1), 84. https://doi.org/10.1504/ijbir.2013.050557

Invention Center (2018). Rheinisch-Westfälische Technische Hochschule Aachen (RWTH), Consortium Benchmarking 2018 "Agile Invention": Evaluation of the Study Results

Jahanshahi, A. A., \& Brem, A. (2017). Does Real Options Reasoning Support or Oppose Project Performance? Empirical Evidence from Electronic Commerce Projects. Project Management Journal, 48(4), 39-54. https://doi.org/10.1177/875697281704800404

Jetter,A., Albar, F., and Sperry, R. (2016). The practice of project management in product development: Insights from the literature and cases in high-tech . Project Management Institute Global Operations Center. Available at: 
https://www.pmi.org/learning/academic-research/the-practice-of-projectmanagement-in-product-developmen

Judi, H. M., \& Beach, R. (2010). Achieving manufacturing flexibility: The role of people, technology, innovation and continuous improvement. International Journal of Innovation and Technology Management, 07(02), 161-181. https://doi.org/10.1142/S0219877010001891

Karlstrom, D. and Runeson P. (2006). Integrating Agile software development into StageGate managed product development. Empirical Software Engineering, 11: 203-225.

Karlstrom, D. and Runeson, P. (2005). Combining Agile methods with Stage-Gate project management. IEEE Software, May-June: 43-49.

Kortelainen, S., \& Lättilä, L. (2013). HYBRID MODELING APPROACH TO COMPETITIVENESS THROUGH FAST STRATEGY. International Journal of Innovation and Technology Management, 10(05), 1340016. https://doi.org/10.1142/s0219877013400166

Kreiner, K. (1995). In search of relevance: project management in drifting environments. Scand. J. Manag. 11: 335-346.

Kreiner, K. (2012). Comments on challenging the rational project environment: the legacy and impact of Christensen and Kreiner's Projektledning i en ofulständig värld. Int. J. Manag. Proj. Bus. 5: 714-717.

LEE, Y., John, C. ST., Fong, E. A., \& Bao, Y. (2018). FLEXIBLE NEW PRODUCT DEVELOPMENT PROCESSES AND APPROPRIABILITY: INTELLECTUAL PROPERTY AND FIRST-MOVER. International Journal of Innovation Management, 22(01), 1850002. https://doi.org/10.1142/s1363919618500020

Lenfle, S. and Loch, C. (2010). Lost roots: How project management came to emphasize control over flexibility and novelty. California Management Review, 53, 1: 32-55.

Miaskiewicz, T. and Kozar, K. A. (2011). Personas and user-centered design: How can personas benefit product design processes? Design Studies, 32, 5: 17-430. https://doi.org/10.1016/j.destud.2011.03.003

Millward, H. U. W., Byrne, C., Walters, A. T., \& Lewis, A. (2006). New product development within small and medium-sized enterprises: Analysis through technology management maps. International Journal of Innovation and Technology Management, 03(03), 283-302. https://doi.org/10.1142/s0219877006000806

Nardelli, G. and Edwards, K. (2018). Co-Developing Agile-Stage-Gate in Danish SMEs. Participatory Innovation Conference 2018, Eskilstuna, Sweden. http://pinc.sdu.dk/assets/track-5e-nardelli-p360-364.pdf

Nicholas, J.M., Steyn, H. (2012). Project Management for Business, Engineering, and Technology, 4 ed. Routledge, New York.

Ovesen, N. (2012). The challenges of becoming Agile: Implementing and conducting scrum in integrated product development. Report from: Department of Architecture \& Design. Aalborg University, Denmark.

Reagan, B. (2012). Going Agile: CA Technologies, Clarity PPM Division's transformative journey. Digital Celerity, San Francisco, CA, Sept 22: http://www.slideshare.net/DCsteve/going-agile-with-ca-clarity-ppm-agile-vision 
Salerno, M. S., Gomes, L. A. D. V., Da Silva, D. O., Bagno, R. B., \& Freitas, S. L. T. U. (2015). Innovation processes: Which process for which project? Technovation, 35, 5970. https://doi.org/10.1016/j.technovation.2014.07.012

Saynisch, M. (2010). Beyond frontiers of traditional project management: an approach to evolutionary, self-organizational principles and the complexity theory-results of the research program, Project Management Journal 41:21-37.

Schmidt, T. S., Weiss, S. and Paetzold, K.. (2018). Agile Development of Physical Products: An Empirical Study About Motivations, Potentials and Applicability: Report, University of the German Federal Armed Forces, Munich, Germany: www.unibw.de/produktentwicklung-en

Schwaber, K. (2004). Agile Project Management with Scrum. Richmond, WA: Microsoft Press.

ScrumInc. (2017). The Scrum Guide. July. http://www.scrumguides.org/scrum-guide.html

Sethi, R. and Iqbal, Z. (2008). Stage-gate controls, learning failure, and adverse effect on novel new products. Journal of Marketing, 72, January: 118-134.

Sommer, A.F., Dukovska-Popovska, I., and Steger-Jensen, K. (2013). Barriers towards integrated product development-Challenges from a holistic project management perspective, International Journal of Project Management, available at: http://dx.doi.org/10.1016/j.ijproman.2013.10.013

Sommer, A.F., Hedegaard, C., Dukovska-Popovska, I. and Steger-Jensen, K. (2015). Improved product development performance through Agile/Stage-Gate hybrids - The next-generation Stage-Gate process? Research-Technology Management, 158, 1, JanFeb: 1-10.

Svejvig, P. and Andersen, P. (2015). Rethinking project management: A structured literature review with a critical look at the brave new world, International Journal of Project Management 33: 278-290.

Sætre, A. S., \& Brun, E. (2012). Strategic management of innovation: Managing exploration-exploitation by balancing creativity and constraint. International Journal of Innovation and Technology Management, 09(04), 1250025. https://doi.org/10.1142/S0219877012500253

Sætre, A. S., \& Brun, E. C. (2013). Ambiguity and Learning in the Innovation Process: Managing Exploitation-Exploitation By Balancing Creativity and Constraint Revisited. International Journal of Innovation and Technology Management, 10(04), 1350014. https://doi.org/10.1142/S0219877013500144

Tesch, J. F., Brillinger, A.-S., \& Bilgeri, D. (2017). INTERNET OF THINGS BUSINESS MODEL INNOVATION AND THE STAGE-GATE PROCESS: AN EXPLORATORY ANALYSIS. International Journal of Innovation Management, 21(05), 1740002. https://doi.org/10.1142/S1363919617400023

Thomas, J. and Mengel, T. (2008). Preparing project managers to deal with complexityadvanced project management education. International Journal of Project Management 26: 304-315.

Tura, N., Hannola, L., \& Pynnönen, M. (2017). Agile Methods for Boosting the Commercialization Process of New Technology. International Journal of Innovation 
$\begin{array}{llll}\text { and Technology } & \text { Management, } & 1750013 .\end{array}$ https://doi.org/10.1142/S0219877017500134

Vedsmand, T., Edwards, K., Hvidt, N., Nielsen, M. and Jørgensen, J. K. (2017a). Agil Stage-Gate ${ }^{\circledR}$ : ny model for udviklingsprojekter $i$ mellemstore virksomheder. Dansk Industri. DOI: http://dx.doi.org/10.11581/DTU:00000028

Vedsmand, T., Edwards, K., Hvidt, N., Nielsen, M. and Jørgensen, J. K. (2017b). Varktøjskasse til Agil Stage-Gate ${ }^{\circledR}:$ Ny model for udviklingsprojekter i mellemstore virksomheder. Dansk Industri. DOI: http://dx.doi.org/10.11581/DTU:00000029

Vedsmand, T., Kielgast, S. and Cooper, R.G. (2016). Integrating Agile with Stage-Gate ${ }^{\circledR}$ - How new Agile-Scrum methods lead to faster and better innovation. Innovation Management SE, Aug 9:1-15.

Walters, A. T., Millward, H. U. W., \& Lewis, A. (2006). Case Studies of Advanced Manufacturing Technology Implementation in Small Companies. International Journal of Innovation \& Technology Management, 3(2), 149-169. Retrieved from http://search.ebscohost.com/login.aspx?direct=true\&db=bth\&AN=21498066\&site=eh ost-live

Yordanova, Z. B. (2018). Lean Startup Method Hampers Breakthrough Innovations and Company's Innovativeness. International Journal of Innovation and Technology Management, 15(02), 1850012. https://doi.org/10.1142/s0219877018500128 